\title{
Coğrafi Bilgi Sistem Analizleri Kullanılarak Toprak ve Arazi Özelliklerinin Değerlendirilmesi: Türkiye, Mardin İli Arazisi
}

\author{
Çağrı MERCAN*, Sezin ARPAĞ \\ Mardin Artuklu Üniversitesi, Savur Meslek Yüksekokulu, Harita ve Kadastro Programı, Mardin, TÜRKIYYE
}

\begin{tabular}{ll}
\hline \multicolumn{1}{c}{ Geliş Tarihi/Received: 07.11.2019 } & Kabul Tarihi/Accepted: 07.02.2020 \\
\hline ORCID ID (Yazar surasına göre / by author order) \\
(D) orcid.org/0000-0003-1694-0024 (D) orcid.org/0000-0002-7555-840X \\
"Sorumlu Yazar/Corresponding Author: cagrimercan@artuklu.edu.tr
\end{tabular}

Öz: Bu çalıșmanın amacı, Coğrafi Bilgi Sistemleri’nden (CBS) faydalanmak suretiyle arazilerin, arazi ve toprak özelliklerinin belirlenmesi ve veri tabanlarının oluşturulmasıdır. Bu amaca yönelik olarak; geçmişte bereketli hilal olarak da adlandırılmış ve verimli tarım arazilerinin bulunduğu yörenin içinde yer alan Türkiye'nin Güneydoğu Anadolu Bölgesi’ndeki Mardin ili arazi ve toprak özellikleri değerlendirilmiştir. Çalışılan alan yaklaşık $8633 \mathrm{~km}^{2}$ olup, araştırmada öncelikle Mardin iline ait topoğrafik haritalar kullanılarak arazinin sayısal yükseklik modeli oluşturulmuştur. Bu haritanın yapımıyla birlikte eğim, bakı, yükselti, kabartı haritaları ve (Mülga) Köy Hizmetleri Genel Müdürlüğü tarafından oluşturulan veriler alınarak, CBS ortamında araziye ait özelliklerin mekânsal ve alansal oranları hesaplanarak haritaları çizilmiştir. Çizilen tüm haritalar ise oluşturulan sayısal yükseklik haritasının üzerine oturtularak topoğrafya verisi ile birlikte incelenip yorumlanmıştır. Çalışma sonucunda elde edilen verilere göre; Mardin ilinin toplam alanının \% 47.54'ünün \% 6'dan düşük eğim değerlerine sahip olduğu ve bu alanların ilin çoğunlukla güney bölgelerinde bulunduğu belirlenmiştir. Mardin ilinde en yoğun bulunan toprak türleri \% 43.65 ile kahverengi orman toprakları ve \% 42.57 ile kırmızımsı kahverengi topraklardır. Arazi kullanımı açısından ilin \% 38.81'lik bölümü meralardan, \% 25.38'lik bölümü ise fundalıklardan olușmaktadır. Erozyon bakımından ilin \% 74.35 'inin orta, şiddetli ve çok şiddetli erozyon içerisinde olduğu görülmüştür. Çalışma alanının \% 28.89'u I., II. ve III. sınıf arazi kabiliyetine sahip alanlardan oluşmaktadır. Toprak derinliği açısından ilin \% 43.13'lük kısmının çok sığ ve sığ toprak özelliğine sahip olduğu tespit edilmiştir. Mardin ilinde tarımsal üretiminin yoğun olduğu arazilerin çoğunlukla yükseklik ve eğim değerleri düşük olan bölgelerde yoğunlaşmış olduğu saptanmıştır. Bölgedeki su probleminin ürün çeşidinde sınırlama meydana getirdiği ve erozyonun bölgenin en ciddi sorunları arasında olduğu belirlenmiştir. Bu problemlerin bertaraf edilmesi yörenin tarımsal üretimine pozitif katkı sağlayacaktır.

Anahtar Kelimeler: Güneydoğu Anadolu Bölgesi, coğrafi bilgi sistemleri, arazi kullanımı, arazi örtüsü, erozyon

\section{The Evaluation of Soil and Land Characteristics by Using Geographic Information System Analysis: Mardin Province Lands, Turkey}

\footnotetext{
Abstract: The purpose of the present study is to determine the soil and land characteristics and create databases by using Geographic Information Systems (GIS). For this purpose, the soil and land characteristics of Mardin Province, which is located in the Southeastern Anatolia Region of Turkey, which is part of so-called "Fertile Crescent" with fertile agricultural lands, were evaluated. The area that was included in the study was approximately $8633 \mathrm{~km}^{2}$, and the digital height model of the area was created by using the topography maps of Mardin Province. With the creation of these maps, the slope, aspect, elevation, relief maps, and the data created by the General Directorate of Village Services were collected and were drawn on the maps by calculating the spatial and areal rates of the area features in the GIS environment. All the maps drawn were placed on the created digital elevation map and examined and interpreted together with the topography data.. According to the data obtained as a result of the study, it was determined that $47.54 \%$ of the total area of Mardin Province has less than $6 \%$ slope values, and these areas are located mostly in the southern regions of the province. The most common soil types in Mardin province are brown forest soils with $43.65 \%$ and reddish-brown soils with $42.57 \%$. In terms of the land usage, $38.81 \%$ of the province consists of pastures, and $25.38 \%$ consists of the shrubs. In terms of erosion, it was determined that $74.35 \%$ of the province has
} 
moderate, severe and very severe erosion risk. A total of $28.89 \%$ of the study area consists of I., II. and III. classes according to land capability. In terms of soil depth, $43.13 \%$ of the province has been found to have very shallow and shallow soil characteristics. It is determined that the lands where agricultural production is intensive in Mardin are mostly concentrated in regions with low altitude and slope values. It has been determined that the water problem in the region creates limitations in the product variety and erosion is among the most serious problems of the region. Elimination of these problems will contribute positively to the agricultural production of the region.

Keywords: Southeast Anatolia Region, geographic information systems, land use, land cover, erosion

\section{Giris}

Tarım, insanoğlunun hayatta kalabilmesi için sürdürülmesi gereken en önemli faaliyet alanlarından birini oluşturmaktadır. Hızlı nüfus artışı, küresel ısınma, su kaynaklarındaki azalma, yanlış tarım ve toprak politikaları gibi olumsuz nedenler, her geçen gün tarımsal üretimi daha da çok tehdit etmektedir. Dünyada 1880 yllından günümüze doğru ortalama $1{ }^{\circ} C^{\prime}$ lik bir sicaklık artışının olduğu (Eryılmaz ve Demirarslan, 2018) ve bu artışın önümüzdeki yıllarda katlanarak devam edeceği belirtilmektedir. Malthus (1998), yapmış olduğu çalışmada gıda üretiminin aritmetik olarak artmasına karşılık, ülkelerin nüfuslarının geometrik olarak arttığını ve bu artış şeklinden ötürü gıda üretiminin artan nüfusa yetmeyeceğini söyleyerek insanlığın ileri tarihlerde açlıkla karşı karşıya geleceğini belirtmiștir. Artan nüfus ve sicaklık beraberinde yanlış tarım ve su politikaları ile birlikte ciddi bir kuraklı tehdidini de oluşturmuştur. Tüm bu durumlar insanoğlunun çevreye karşı daha dikkatli davranmasını ve elindeki mevcut kaynakları etkin bir şekilde tanıyıp kullanmasını gerektirmektedir.

Toprak bilindiği üzere tarımsal üretimin temelini oluşturmaktadır ve sürdürülebilir verimli bir üretim için temel özelliklerinin bilinmesi gerekmektedir. İnsanoğlu yaşadığı coğrafyayı ve toprağ 1 tanıdığı ölçüde; elindeki arazinin temel özelliklerini, hangi bitki türlerinin nerelerde yetiştirilebileceğini, tarımsal ürünlerin gereksinimlerinin neler olabileceğini, bitkilerin yetiştirilmesinde karşılaşılabilecek problemler hakkında daha sağlıklı çözümler üretebilecektir. Bu tür sorunların çözülmesi için gerekli temel verilerden biri de arazi ve toprak özelliklerinin bilinmesidir. Türkiye'de ilk toprak etüt çalışmaları 1950'li yıllarda başlamış; 1966-1977 yılları arasında (Mülga) Topraksu Genel Müdürlüğü tarafından, 1/25000 ölçekli topoğrafik haritalar kullanılarak istikşafi düzeyde ilk toprak haritaları oluşturulmuştur. Çalışmalar sonucunda pedogenetik (morfogenetik) sınıflama sistemi olan 1938 tarihli Amerikan sınıflama sistemi kullanılmış ve 1/100000 ölçekli il ve $1 / 200000$ ölçekli havza raporları yayınlanmıștır (Canpolat, 1981; Özkalayc1 ve ark 2001; Dengiz ve Sarıŏlu, 2011; Özyazıcı ve ark., 2014; Karaca ve ark., 2019). Daha sonraki y1llarda, (Mülga) Köy Hizmetleri Genel Müdürlüğü tarafından, Türkiye Toprakları Verimlilik Envanteri (TOVEP) çalışması başlatılmış ve bu çalışmalar neticesinde Türkiye topraklarının il düzeyinde verimlilik durumları ve ekonomik öneme sahip bitkilerin gübre ihtiyaçları belirlenerek sonuçlar 1/100000 ölçekli haritalarla birlikte il raporları halinde yayınlanmıştır. Bu bağlamda, Mardin ilinin toprak sistemleri ile ilgili tek veri kaynağı da eski toprak sinıflama sistemine göre hazırlanan 1/100000 ölçekli haritalardır (Anonim, 1970). Bu haritaların içerisinde toprağın türü ve derinliği, erozyon derecesi, eğim özellikleri, alkalilik, kayalık-taşlık durumu, arazi kullanım kabiliyeti gibi bilgiler bulunmaktadır. Mevcut olan bu haritalar, günümüzde kullanılan detaylı toprak etütleri neticesinde oluşturulan Toprak Taksonomisi'ne göre sınıflandırılmamış olup, haritaların ölçekleri de yapılacak ayrıntılı çalışmalarda verimli bir şekilde kullanılamamaktadır. Bu sorun gerek Mardin ve gerekse de Türkiye açısından büyük bir sorun oluşturmaktadır.

Temel bilgi teknolojilerinde meydana gelen bilimsel gelişmeler ile birlikte Coğrafi Bilgi Sistemleri (CBS) denen kavram ve birçok bilgisayar programı da hayatımıza girmiştir. $\mathrm{Bu}$ sistemin gelişmesi ile birlikte birçok alanda ortaya çıkan yenilikler tarım alanında da görülmeye başlanmıştır. $\mathrm{Bu}$ teknoloji ile birçok tarımsal bilginin analizi, tarımda verimliliğe önemli katkılar sunmuştur. Coğrafi bilgi sistemlerinin gelişmesi ile birlikte; toprak özelliklerine ait dağılım haritalarının oluşturulması, bitki besin elementlerinin eksiklik-yeterlilik-toksiklik düzeylerinin ortaya konması, ürün desenlerinin belirlenmesi, hastalıklı bitkilerin dağılımı, erozyonlu alanlara ait risk haritalarının oluşturulması, rekolte tahminleri, belirli bir bitki türü için en uygun arazinin belirlenmesi gibi birçok tarımsal alanda önemli gelişmeler sağlanmıştır (Yomralığlu, 2005; Çorumluoğlu ve ark. 2007; Demirci, 2008; Karabulut ve Küçükönder, 2008; Kavzoğlu ve Çölkesen, 2011; Öztürk Coşar ve Engindeniz, 2011; Özyazıcı ve ark., 2013, 2014, 2015, 2016, 2017a, 2017b; Özşahin, 2014; Aydan ve ark., 2016; Dengiz ve Özyazıc1, 2018; Karaca ve ark., 2019). 
Bu çalışma ile (Mülga) Köy Hizmetleri Genel Müdürlüğü tarafından oluşturulmuş olan Mardin ili toprak haritaları ve Harita Genel Müdürlüğü tarafından üretilmiş topoğrafik haritaların CBS ortaminda incelenip, analiz edilmesi ve sonuçlarının ortaya konulması amaçlamaktadır.

\section{Materyal ve Yöntem}

Çalışma alanını oluşturan Mardin ili, Güneydoğu Anadolu Bölgesi'nin Dicle bölümünde 3956'$42^{\circ} 54^{\prime}$ doğu boylamları ve $36^{\circ} 55^{\prime}-38^{\circ} 51^{\prime}$ kuzey enlemlerinde arasında bulunmaktadır. Mardin ili Yukarı Mezopotamya bölgesinde kurulmuş olup, birçok tahıl türünün ilk kez evcilleştirildiği, yoğun tarımsal faaliyetlerin yapıldığ 1 bereketli hilal olarak adlandırılan en eski şehirlerinden biridir (Zohary ve Hopf, 2000; Atar, 2017). Kuzeyde Batman ve Diyarbakır, güneyde Suriye, batıda Şanlıurfa, doğuda Şırnak ve kuzeydoğuda Siirt illeri bulunmaktadır. Mardin'in Artuklu, Kızıltepe, Dargeçit, Derik, Midyat, Mazıdağı, Nusaybin, Ömerli, Yeşilli ve Savur olmak üzere toplam on ilçesi bulunmaktadır (Şekil 1). Mardin ilinin ortalama rakımı yaklaşık olarak 1083 metredir. Bölgede bulunan dağlar, Arap plakasının Anadolu plakasını tektonik olarak sıkıştırmasından ötürü çoğunlukla doğu-batı uzanımlı olarak oluşmuşlardır. Dağların büyük bir kısmı Eosen ve Kretase yaşlı kireçtaşı, marn ve kalkerlerden oluşmaktadır. Bunun dişında Derik bölgesinde Karacadağ volkanının Geç Kuvaterner döneminde gösterdiği faaliyetler neticesinde oluşmuş piroklastik ve volkanik kayaçlar bulunmaktadır (Anonim, 2002). Dilek Dağı (1231 m), Ziyaret Tepe $(1160 \mathrm{~m})$, Kalınca Tepe $(1134 \mathrm{~m})$ ve Alem Dağı (1041 m) yörenin önemli yükseltileridir. Mardin ilinin, \% 26.25'i 349-569 m, \% 11.87'si 569-755 m, $\%$ 16.73'ü 755-906 m, \% 28.06's1 906-1028 m ve \% 17.09'u 1028-1451 m arasında değişen yükseklik değerlerine ve alansal oranlara sahiptir (Şekil 2). Önemli akarsuları arasında Gümüş Çayı (Zergan), Çağ Suyu, Savur Çayı ve Buğur Çayı söylenebilir.

Mardin ili iklimi, Akdeniz iklimine benzer özellikler gösterir. Yazlar çok sıcak ve oldukça kurak geçerken, kışlar ise bol yağışlı ve soğuktur. Kış aylarında dağlık alanlarda zaman zaman kar yağışları görülürken, ovalarda ise az miktarda kalıcı olmayan kar yağışları görülebilmektedir. Mardin ilinin uzun yıllar (1941-2018) iklim verilerine göre; yıllık ortalama sicaklık değeri $16.1^{\circ} \mathrm{C}$, ortalama en yüksek sıcaklık değeri $20.1{ }^{\circ} \mathrm{C}$ ve en düşük sıcaklık ortalaması ise $12.2{ }^{\circ} \mathrm{C}$ 'dir. Aynı dönemde, belirlenen en düşük sıcaklık $-14{ }^{\circ} \mathrm{C}$ iken, en yüksek sıcaklık $42.5{ }^{\circ} \mathrm{C}$ olarak ölçülmüş; yıllık ortalama güneşlenme süresi 96.9 saat, bir yıldaki ortalama yağışlı gün sayısı 78.1 gün ve aylık toplam yağış miktarı ortalaması ise $667.8 \mathrm{~mm}$ olmuştur (Anonim, 2019).

Araştırma alanının arazi ve toprak özelliklerinin saptanarak incelenmesi amacıyla Harita Genel Müdürlügü̈nün ürettiği 1/25000 ölçekli topoğrafik haritalar ve (Mülga) Köy Hizmetleri Genel Müdürlüğü (KHGM)'nün hazırlamış olduğu toprak haritaları (Anonim, 1997) kullanılmıştır. Haritalar,

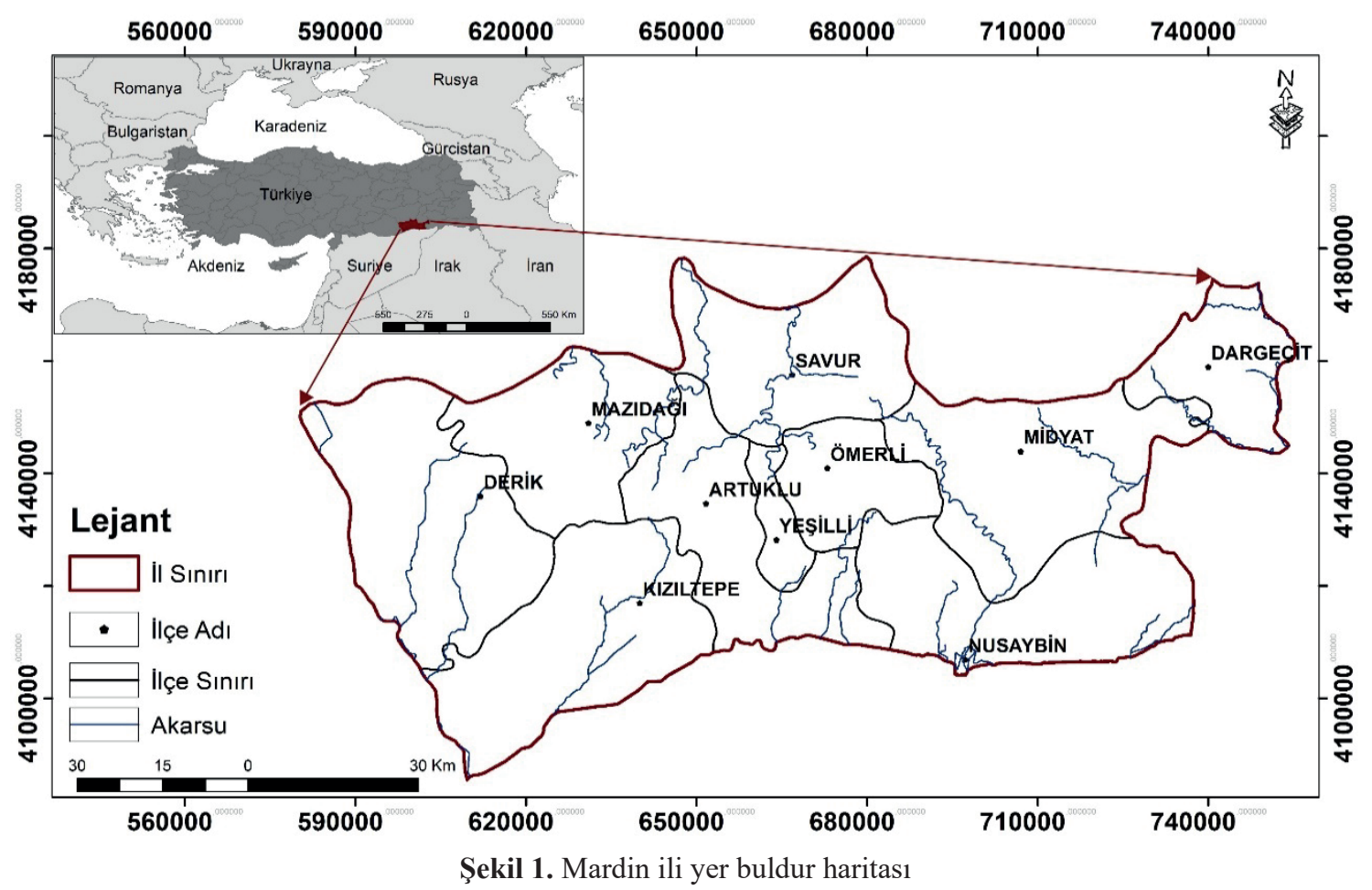

Türkiye Tarımsal Araştırmalar Dergisi - Turkish Journal of Agricultural Research 


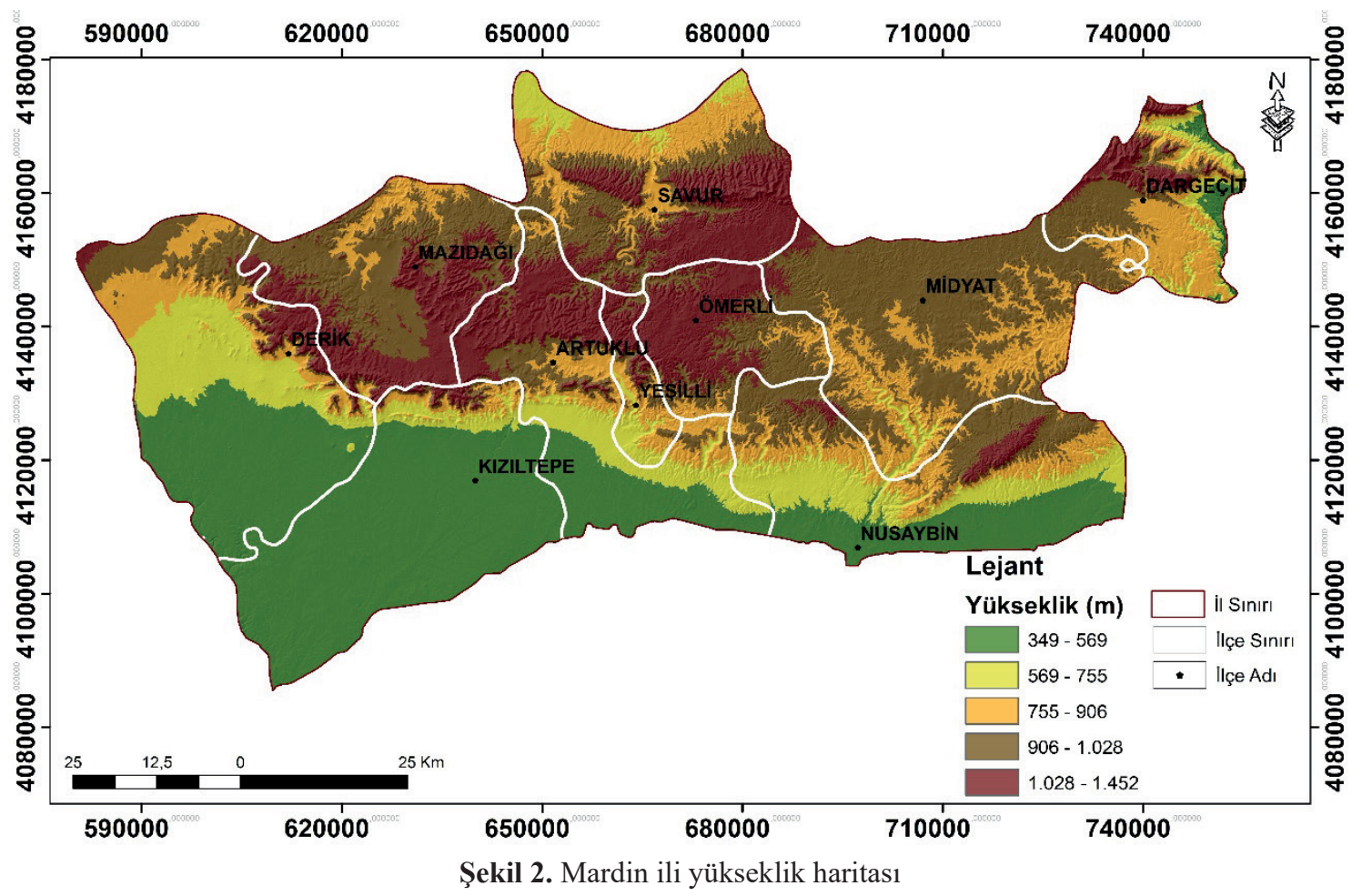

“ArcGis 10.5" ve "Global Mapper 19" yazılımları kullanılarak sayısallaştırılmıştır. Daha sonra bu haritalardan; sayısal yükseklik, kabartı, eğim, bakı haritaları oluşturulmuştur. Oluşturulan tüm haritalar için CBS ortamında bir veri tabanı düzenlenmiştir. Düzenlenen verilerden toprak grupları, erozyon, arazi kullanım kabiliyeti, toprak derinliği, arazi kullanımı gibi tematik haritalar üretilmiştir. Hazırlanmış olan kabartı haritası (Şekil 3) arazinin daha iyi anlaşılabilmesi için yapılmış olan tüm haritalar ile çakıştırılarak üç boyutlu haritalar oluşturulmuştur. Elde edilen her haritadan sonra, o haritayı oluşturan öğelerin kapladıkları alansal ve oransal dağılımlar hesaplanmıştır.

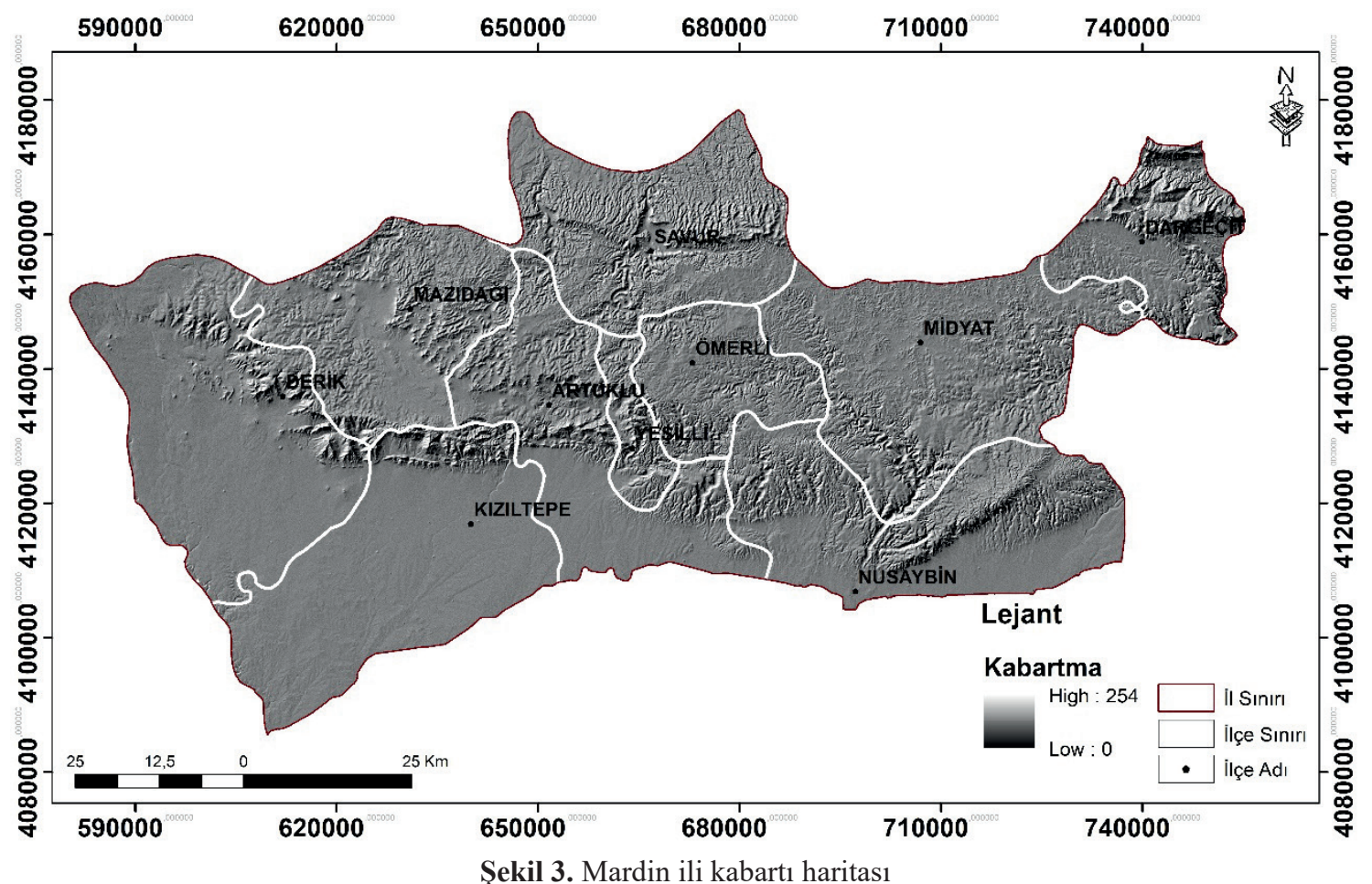




\section{Bulgular ve Tartışma}

\subsection{Mardin ilinin temel arazi özellikleri}

Eğim: Belirli bir bölgedeki arazinin eğim derecesi; yüzeysel akış, toprak erozyonu, toprak oluşumu ve çeşitliliği gibi birçok faktörü etkilemektedir (Şensoy ve Palta, 2009; Dengiz ve ark., 2013). Mardin ili eğim özellikleri incelendiği zaman \% 47.54'lük bir bölüm \% 6'nın altındaki eğim değerlerine sahiptir. $\mathrm{Bu}$ düşük eğim derecesine sahip alanlar tarım için oldukça elverişli olup, çoğunlukla Kızıltepe ilçesinde bulunmaktadır. İlin \% 37.78'lik bir bölümü ise \% 6-30 arasında değişen eğim değerlerinde bulunmaktadır. İnceleme alanının \%5.35'lik bir kesimi ise \%30 un üzerindeki eğim değerlerine sahiptir (Tablo 1). Bu yüksek eğim özellikleri ilin özellikle Dargeçit ve Artuklu ilçesinin güneyinde yükselen doğu-batı uzanımlı dağ kuşağı boyunca ve Nusaybin'in kuzeydoğu bölgesindeki dağlık alanlarda görülmektedir (Şekil 4).

Tablo 1. Mardin ili eğim sınıfları

\begin{tabular}{lcc}
\hline Eğim (\%) & Alan $\left(\mathrm{km}^{2}\right)$ & Oran $(\%)$ \\
\hline $0-2$ & 1569.833 & 18.18 \\
$2-6$ & 2534.677 & 29.36 \\
$6-12$ & 1834.571 & 21.25 \\
$12-20$ & 1427.095 & 16.53 \\
$20-30$ & 805.599 & 9.33 \\
$30+$ & 461.438 & 5.35 \\
\hline Toplam & 8633.21 & 100.00 \\
\hline
\end{tabular}

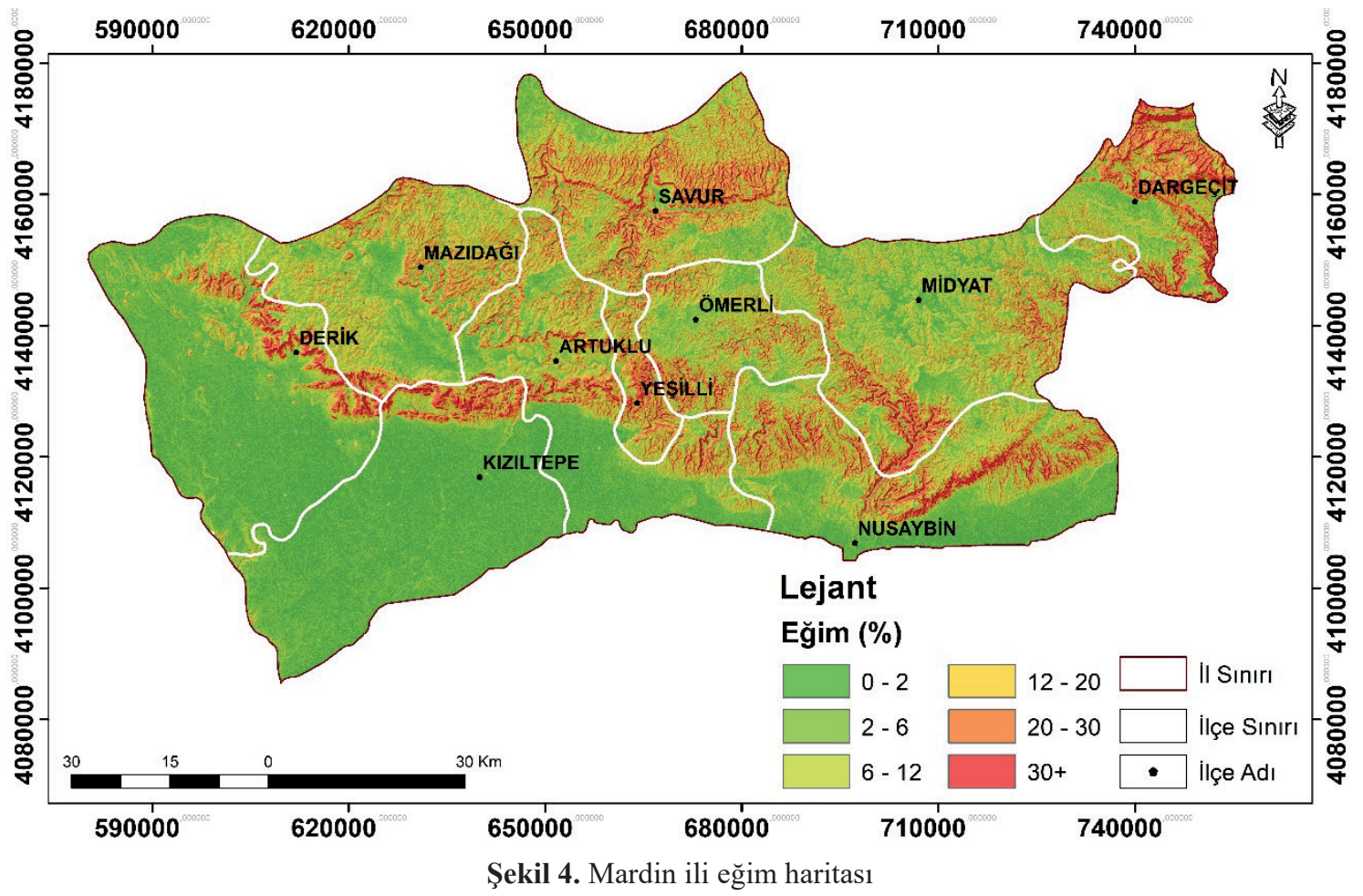

Bakl: Bakı haritaları sayısal arazi modelindeki her hücre için kuzeye göre hesaplanmış yön değerlerinin tematik aralıklar ile gösterilmesi şeklinde oluşturulur. İneleme alanının bakı haritası incelendiğinde Kızıltepe ve Nusaybin ilçelerinin büyük bir bölümünün bakı yönünün güneygüneybatı yönünde olduğu görülmektedir (Şekil 5). Alansal olarak güney-güneydoğu ve güneybatı yönüne bakan bakı alanının \% 43.88, kuzeykuzeydoğu ve kuzeybatı yönüne bakan bak1 alanının ise \% 30.24 olduğu görülmektedir (Tablo 2).

Büyük toprak grubu: Mardin ilinin toprak türleri incelendiği zaman baskın olarak iki farklı toprak türünün varlığı göze çarpmaktadır. Bunlarda birincisi ilin \% 46.65'llk bir bölümünü kaplayan kahverengi orman topraklarıdır. İkinci kısım ise ilin \% 42.57'lik bir bölümünü içeren kırmızımsı kahverengi topraklardır. Bunların dışında özellikle akarsuların olduğu alanlarda alüvyal toprakların (\% 0.43), Derik bölgesinde ise Karacadağ volkanının ürünlerinin görüldüğü bazaltik toprakların (\% 5.17), Derik ilçesinin doğu kısmında ise kireçsiz kahverengi orman topraklarının (\% 2.37), Midyat ilçesinin çeşitli yerlerinde ve Nusaybin'in kuzeydoğusunda, Artuklu ilçesinin güneyinde bulunan doğu-batı uzanımlı dağların güney taraflarında ise parça parça kolüvyal toprakların (\% 3.61) varlığı gözlenmektedir (Şekil 6, Tablo 3). 

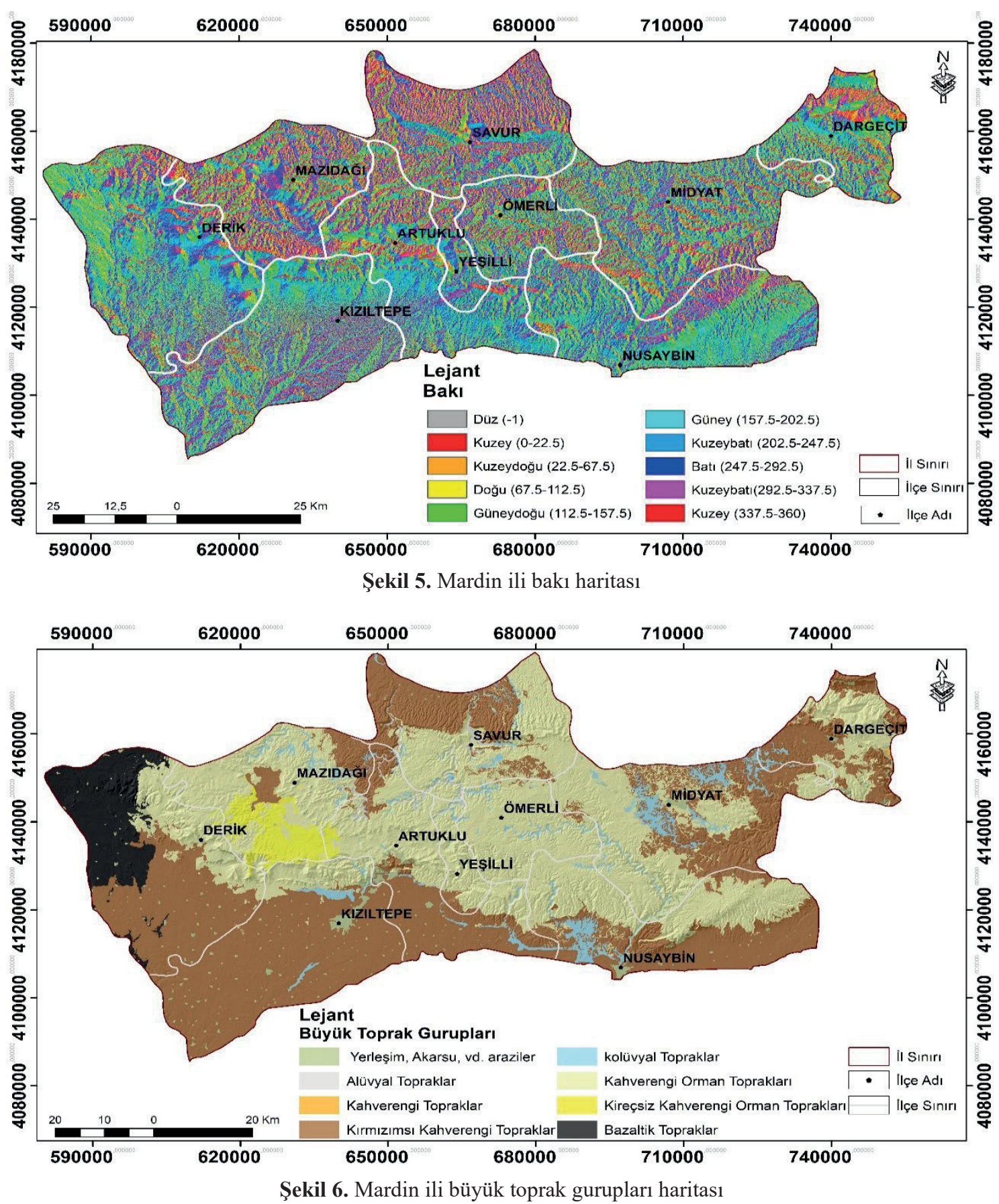

Tablo 2. Mardin ili bakı sinıfları

\begin{tabular}{lcc}
\hline Bak1 & Alan $\left(\mathrm{km}^{2}\right)$ & Oran (\%) \\
\hline Düz & 37.662 & 0.44 \\
Kuzey & 447.157 & 5.18 \\
Kuzeydoğu & 890.590 & 10.32 \\
Doğu & 1104.756 & 12.8 \\
Güneydoğu & 1258.348 & 14.58 \\
Güney & 1301.221 & 15.07 \\
Güneybatı & 1228.683 & 14.23 \\
Batı & 1097.668 & 12.71 \\
Kuzeybatı & 909.948 & 10.54 \\
Kuzey & 357.175 & 4.14 \\
\hline Toplam & 8633.21 & 100.00 \\
\hline
\end{tabular}

Tablo 3. Mardin ili büyük toprak grupları sınıfları

\begin{tabular}{lcc}
\hline Büyük toprak grupları & $\begin{array}{c}\text { Alan } \\
\left(\mathrm{km}^{2}\right)\end{array}$ & $\begin{array}{c}\text { Oran } \\
(\%)\end{array}$ \\
\hline Yerleşim alan1, nehir vd. & 187.25 & 2.17 \\
Alüvyal topraklar & 37.32 & 0.43 \\
Kahverengi topraklar & 1.84 & 0.02 \\
Kırmızıms1 kahverengi topraklar & 3675.25 & 42.57 \\
Kolüvyal topraklar & 311.88 & 3.61 \\
Kahverengi orman toprakları & 3768.53 & 43.65 \\
Kireçsiz kahverengi orman & 204.47 & 2.37 \\
toprakları & 446.68 & 5.17 \\
Bazaltik topraklar & 8633.21 & 100.00 \\
\hline Toplam & & \\
\hline
\end{tabular}


Arazi kullanımı: Arazi kullanım haritası incelendiği zaman neredeyse tüm ilçelerde mera alanlarının bulunduğu ve meraların ilin \% 38.81'ini kapladığı görülmektedir. Meralar çoğunlukla Savur ilinin kuzeyi, Midyat ilçesi ve Derik bölgesinin batısında oldukça yaygın bir şekilde bulunmaktadır. Mera alanlarından sonra ise \% 25.38 oran ile fundalıkların varlığı görülmektedir. Mardin ili sulama yönünden problemli, kurak bir şehirdir ve bu durum arazi kulanımına da yansımaktadır. Özellikle Kızıltepe bölgesinde çok yaygın olarak yapılan kuru tarım (nadassız) ilin yaklaşık \% 22.68'lik bir bölümünü oluşturmaktadır. Nadaslı kuru tarım ise \% 3.76 oranı ile nispeten daha az oranlarda ve çoğunlukla Derik ilçesinin güney bölgelerinde gözlenmektedir. Nusaybin ilçesi ve Savur ilçesinde ise var olan akarsuların da yardımı ile sulu tarım yapılmakta; sulu tarımın il genelindeki oranı ise \% 1.59 ile oldukça düşük düzeyde olduğu görülmektedir. Ömerli ve Midyat ilçeleri başta olmak üzere bir çok alanda arazilerin bağ (kuru) olarak da kullanılmaktadır (\% 3.74). Artuklu ilçesinde arazi kullanımı açısından yoğun olarak bahçe tarımının (kuru) varlığı göze çarpmakta; bu alan ilin oldukça küçük bir kısmını (\% 0.74) kapsamaktadır. Derik ilçesinde ise \% 0.04'lük bir alanda zeytin üretimi söz konusudur. Mardin ilinde orman varlığ $\breve{1}_{1}$ ise $\% \quad 0.74$ ile neredeyse yok denecek kadar azdır ve bu alan Derik bölgesinde yoğunlaşmıştır (Şekil 7, Tablo 4).
Tablo 4. Mardin ili arazi kullanımı sınıfları

\begin{tabular}{lcc}
\hline Arazi kullanımı & Alan $\left(\mathrm{km}^{2}\right)$ & Oran $(\%)$ \\
\hline Yerleşim alanı, nehir vd. & 193.60 & 2.24 \\
Bahçe (kuru) & 63.62 & 0.74 \\
Fundalık alan & 2191.50 & 25.38 \\
Kuru tarım (nadaslı) & 324.40 & 3.76 \\
Mera alanı & 3350.93 & 38.81 \\
Kuru tarım (nadassız) & 1957.79 & 22.68 \\
Ormanlık alan & 14.32 & 0.17 \\
Sulu tarım & 136.87 & 1.59 \\
Sulu tarım (yetersiz) & 74.67 & 0.86 \\
Bağ (kuru) & 322.49 & 3.74 \\
Zeytinlik & 3.03 & 0.04 \\
\hline Toplam & 8633.21 & 100.00 \\
\hline
\end{tabular}

Çalışma alanının güncel arazi örtüsünün ortaya konulması amacıyla 2018 yılında üretilmiş olan CORINE sinıflama sistemi de incelenmiştir (Anonim, 2018). Bu sinflama sistemine göre çalışma alanının \% 24.51'lik bir bölümünde sürekli sulanan arazilerin varlığı göze çarpmaktadır ve bu alanlar bölgenin özellikle güney kısımlarında bulunmaktadır. Anonim (1970)'e göre, 1970 yılındaki arazi örtüsü haritasına kıyasla sürekli sulanan arazilerin oranındaki artış dikkat çekicidir. Çalışma alanının \% 18.57'lik bir bölümü geçici orman-çalılıklardan oluşmaktadır. Kızıltepe ve Derik ilçelerinde pek gözlenmeyen geçici ormançalılık birimi özellikle topoğrafik olarak yüksek kesimlerde yaygın olarak bulunmaktadır. Arazinin \% 15.67'lik bir kısmında seyrek bitkili alanlar

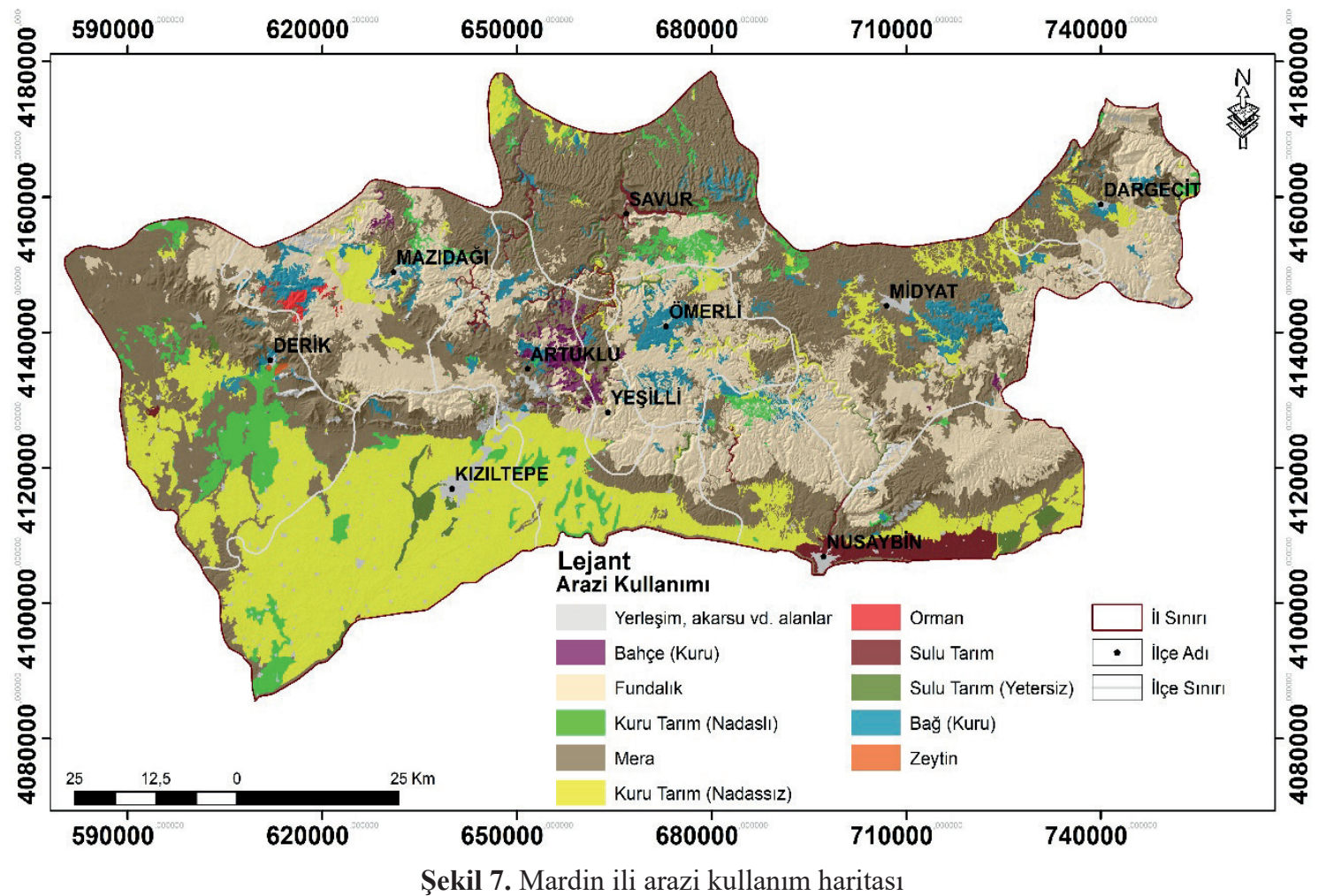

Türkiye Tarımsal Araştırmalar Dergisi - Turkish Journal of Agricultural Research 
bulunmaktadır. Bu alanlar özellikle Savur ilçesi, Nusaybin'in kuzey bölgeleri ile Artuklu ve Yeşilli ilçelerinde parça parça görülmektedir. İnceleme alanının \% 11.33'lük alanında ise doğal bitki örtüsü ile birlikte bulunan tarım ürünlerinin varlığg görülmektedir. $\mathrm{Bu}$ alanlar çoğunlukla Ömerli ilçesinin bulunduğu alanda yoğunlaşmaktadır. Arazinin \% 10.26'llk bir bölümünde ise doğal çayırlık alanların bulunduğu anlaşılmaktadır. Doğal çayırlık alanlar özellikle Nusaybin, Derik ve Dargeçit ilçelerinde gözlenmektedir. Bunların dışında inceleme alanının geriye kalan \% 19.66'lık bölümünde ise farklı örtü birimleri oldukça küçük alanlarda parça parça bulunmaktadır (Şekil 8).

Erozyon: Mardin ili erozyon haritası incelendiğinde; erozyonun ilin \% $39.28^{\prime}$ inde şiddetli olarak görüldüğü, \% 25.31'inde çok şiddetli, \% 9.76'sında orta şiddetli ve \% 23.48'lik bir alanda ise çok az veya hiç olmadığ görülmektedir. Erozyon tehlikesi açısından en az riskli alanların çoğunlukla Kızıltepe bölgesinde olduğu söylenebilir. İl genelinde erozyon büyük bir tehlike unsuru oluşturmaktadır. Eğimli, topoğrafik olarak yüksek ve bitki örtüsü açısından fakir olan bölgelerde bu tehlike daha da büyümektedir (Şekil 9, Tablo 5).

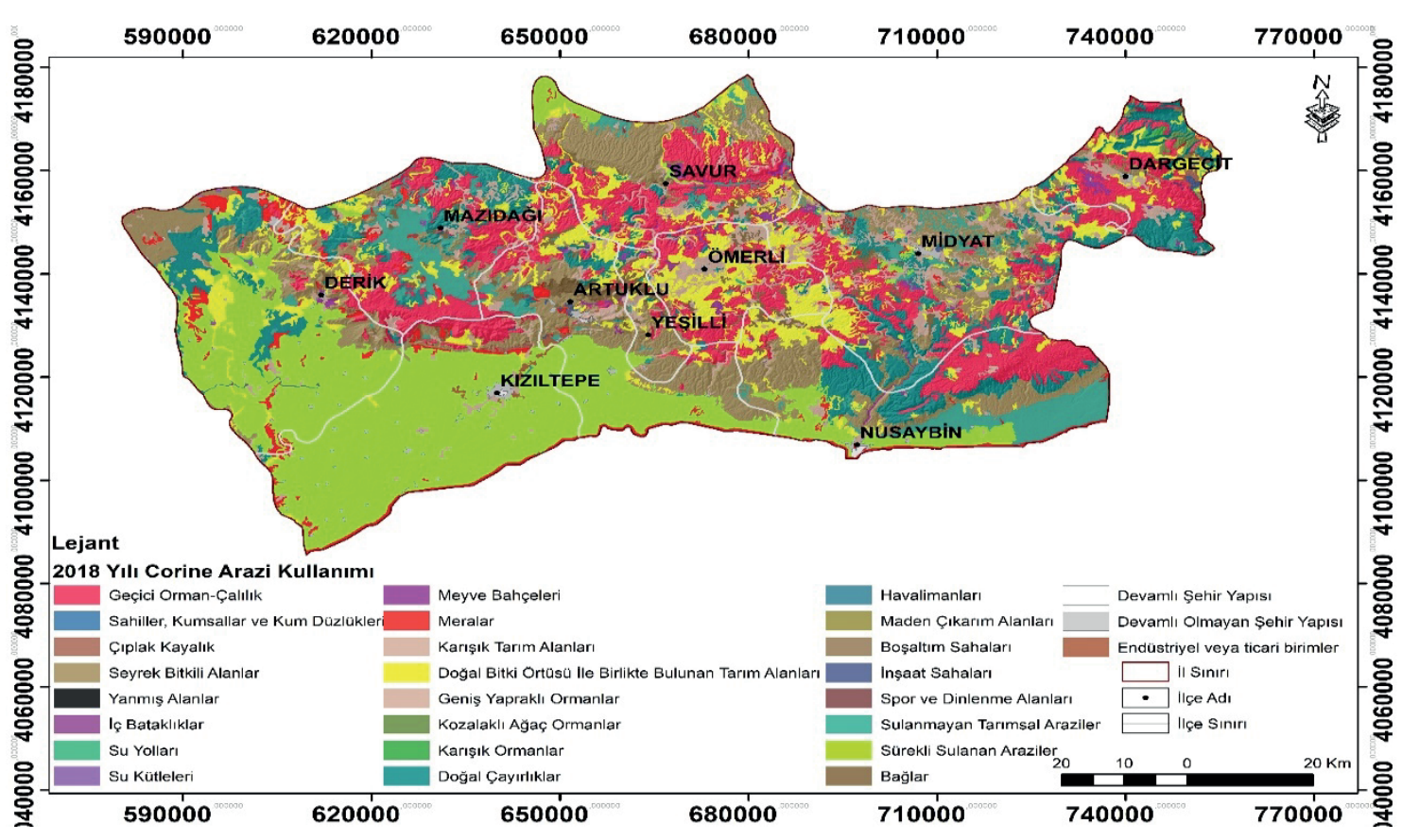

Şekil 8. Güncel arazi kullanım haritası

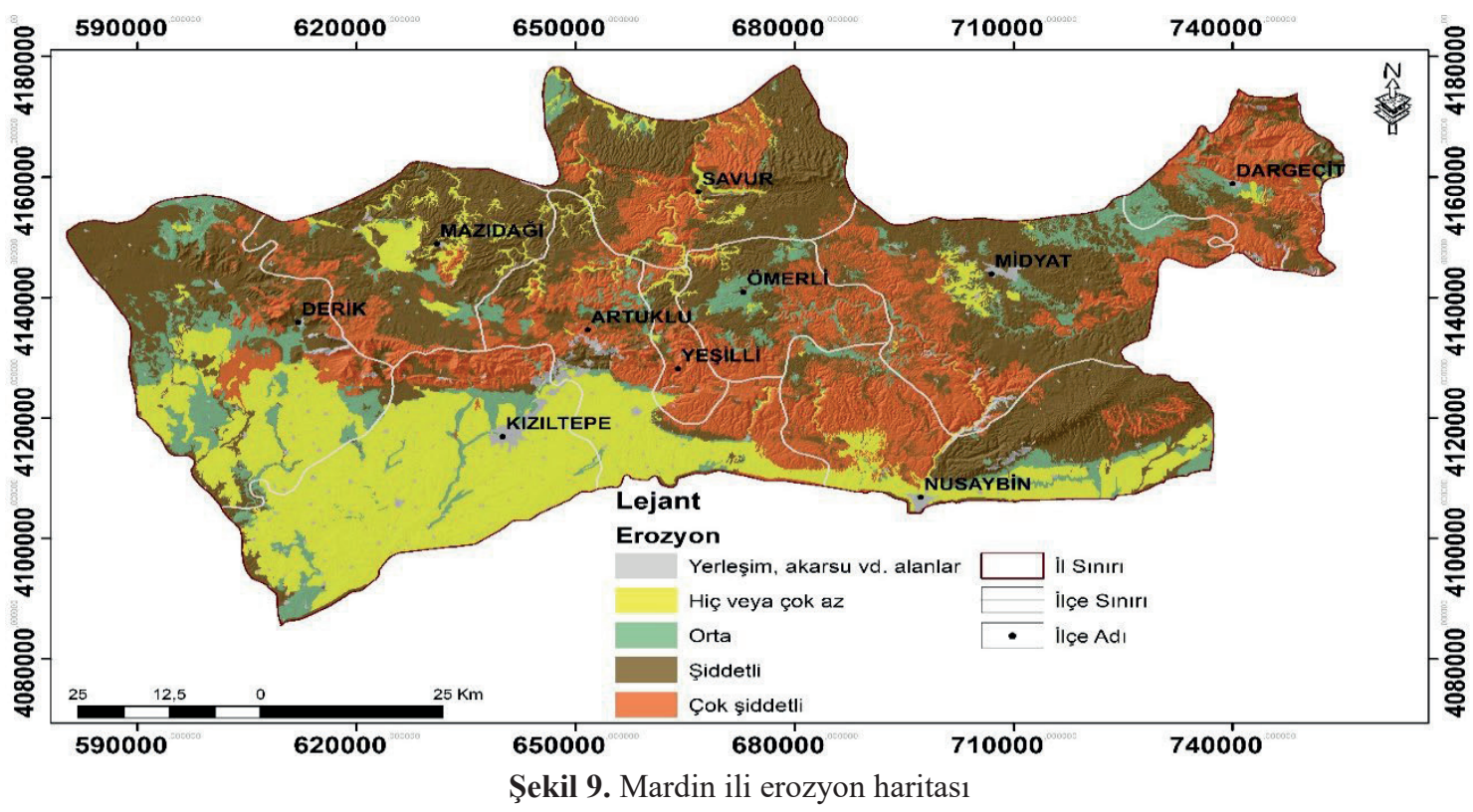


Tablo 5. Mardin ili erozyon sinıfları

\begin{tabular}{lcc}
\hline Erozyon & Alan $\left(\mathrm{km}^{2}\right)$ & Oran $(\%)$ \\
\hline Yerleşim alanı, nehir vd. & 187.253 & 2.17 \\
Hiç veya çok az & 2026.982 & 23.48 \\
Orta & 842.711 & 9.76 \\
Şiddetli & 3390.921 & 39.28 \\
Çok şiddetli & 2185.344 & 25.31 \\
\hline Toplam & 8633.21 & 100.00 \\
\hline
\end{tabular}

Arazi kullanım kabiliyeti: Arazi kullanım kabiliyeti haritaları incelendiğinde; ilin \% 16.48'i I. sınıf, \% 9.73'ü II. sınıf, \% 2.68'i ise III. sınıf verimli arazi olarak değerlendirilebilir. Bu verimli araziler çoğunlukla Kızıltepe ilçesinde I. sınıf, Ömerli ve Nusaybin ilçelerinde ise II. ve III. sınıf araziler olarak göze çarpmaktadır. İlin \% 49.23'lük büyük bir kısmını VII. sınıf araziler oluşturmaktadır. Bu sinıfı \% 19.16 oranı ile VI. sinıf araziler takip etmekte; VIII. sinıf araziler ise ilin \% 0.63 'lük bir kısmını kaplamaktadır (Tablo 6, Şekil 10).

Tablo 6. Mardin ili arazi kullanım kabiliyeti sınıfları

\begin{tabular}{lcc}
\hline Arazi kullanım kabiliyeti & Alan $\left(\mathrm{km}^{2}\right)$ & Oran $(\%)$ \\
\hline Yerleşim alanı, nehir vd. & 133.117 & 1.54 \\
I. sınıf & 1423.109 & 16.48 \\
II. sınıf & 840.439 & 9.73 \\
III. sınıf & 230.962 & 2.68 \\
IV. sınıf & 47.397 & 0.55 \\
VI. sınıf & 1654.108 & 19.16 \\
VII. sınıf & 4249.944 & 49.23 \\
VIII. sınıf & 54.136 & 0.63 \\
\hline Toplam & 8633.21 & 100.00 \\
\hline
\end{tabular}

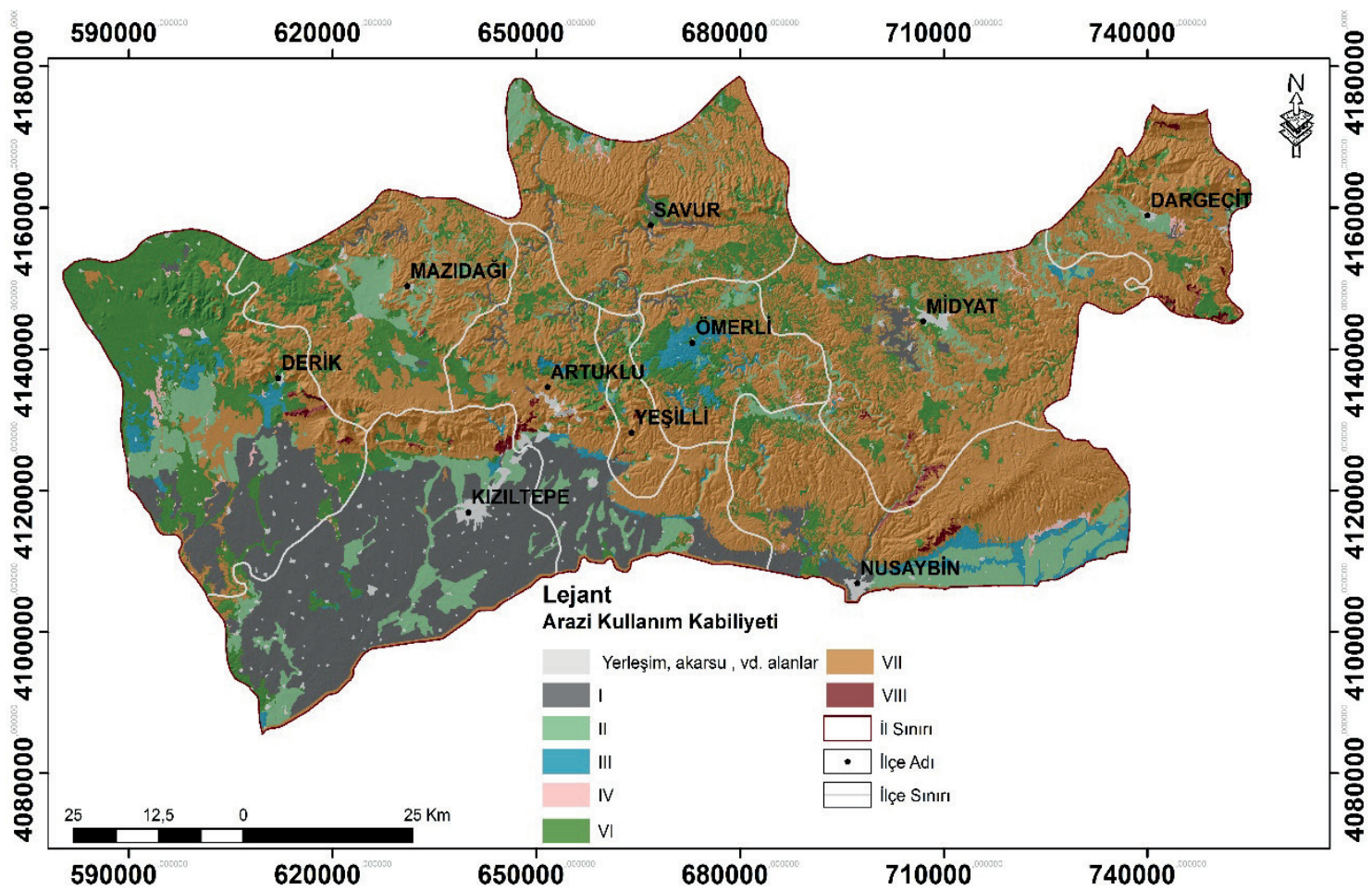

Şekil 10. Mardin ili arazi kullanım kabiliyeti haritası

Toprak derinliği: Bitki köklerinin gelişebilmesi, toprakta su, mineral ve besin maddelerinin tutulması açısından kritik öneme sahip olan toprak derinliği, Mardin ili için incelendiğinde, \% 32.75 oran ile çok sı̆̆ derinlikte $(0-20 \mathrm{~cm})$ toprağın büyük alanlar kapladığı görülmektedir. Toprağın derin $(90+\mathrm{cm})$-orta derin $(90-50 \mathrm{~cm})$ olduğu alanlar ise \% 27.16'lık bir oranla çoğunlukla Kızıltepe bölgesinde bulunmaktadır. Derik ilçesinin batı kesimleri çoğunlukla sı̆̆ $(50-20 \mathrm{~cm})$ topraklar olup, il bazında yaklaşı
$\%$ 10.38'lik orana sahiptir (Tablo 7, Şekil 11).

Tablo 7. Mardin ili toprak derinliği sınıfları

\begin{tabular}{lcc}
\hline Toprak derinliği $(\mathrm{cm})$ & Alan $\left(\mathrm{km}^{2}\right)$ & Oran $(\%)$ \\
\hline Yerleşim alanı, nehir vd. & 187.253 & 2.17 \\
Derin $(90+)$ & 1362.854 & 15.79 \\
Orta Derin (90-50) & 981.820 & 11.37 \\
Sı ̆ $(50-20)$ & 896.458 & 10.38 \\
Çok Siğ $(20-0)$ & 2827.624 & 32.75 \\
Litozolik & 2377.204 & 27.54 \\
\hline Toplam & 8633.21 & 100.00 \\
\hline
\end{tabular}




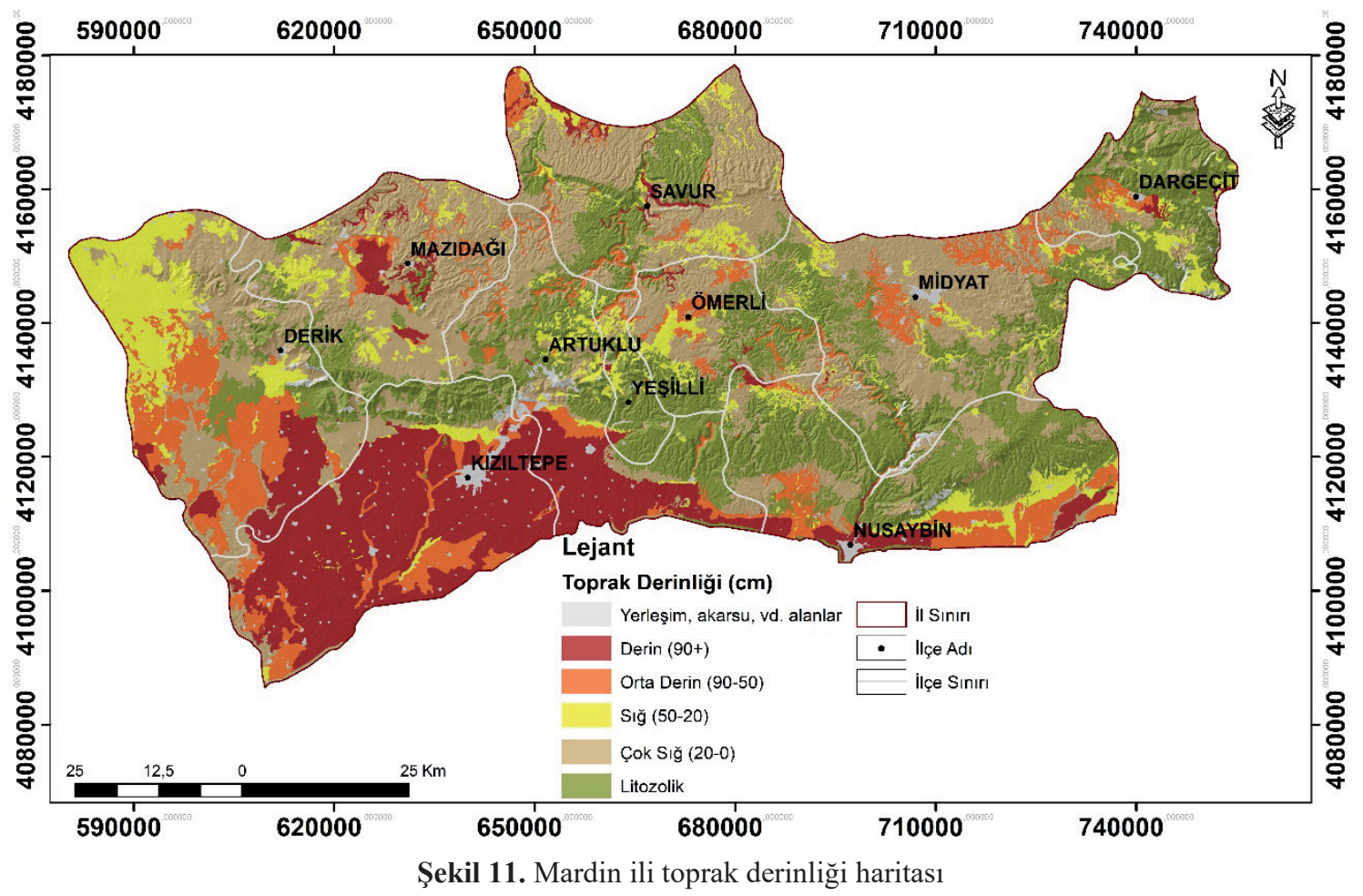

\section{Sonuçlar}

Tarih boyunca devletlerin ekonomik refah düzeyleri doğal kaynaklarının zenginliğine ve bu kaynaklarını tanıyarak etkin bir şekilde kullanmalarına bağlı olmuştur. Toplumlar yaşadıkları toprakları tanıdıkları ölçüde verim almış ve böylelikle gelişebilmişlerdir. Bu çalışmada geçmiş dönemde toprak ile ilgili olarak yapılmış olan çalışmalar, güncel arazi örtüsü çalışmaları, topoğrafya özellikleri de dâhil edilerek CBS ortamında sayısallaştırılarak analiz edilmiştir. Bu şekliyle iki boyutlu olarak anlaşılması güç veriler üçüncü boyut yardımı ile çok daha anlaşıllabilir olmuştur.

Yapılan bu çalışma neticesinde arazilerin kullanım kabiliyeti, eğim ve yüksekliği bakımından tarımsal üretime uygun olup olmadığı, mevcut problemler, rakamsal ve görsel veriler 1 şı̆̆ında ortaya konulmuştur. Mardin ilinin özellikle güney bölgesinde daha yaygın olarak yer alan eğimi düşük, topografik olarak alçak alanların tarım için oldukça elverişli olduğu saptanmıştır. Topografik olarak yüksek olan kesimlerin tarımsal üretim açısından sınırlı imkânlar sunduğu belirlenmiştir. Bölgede genel olarak gözlenen bir sulama problemi bulunmaktadır. Bu sorunun çözümü ile bölgede mevcut olan ürün çeşitlerinde ve miktarlarında artış meydana gelebilecektir. Eğim değeri düşük olan bölgelerin dışında kalan alanların ise büyük oranda erozyon tehdidi ile karşı karşıya olduğu belirlenmiştir. $\mathrm{Bu}$ alanlarda erozyonu önleme ve rehabilitasyon çalışmalarının hızlı bir şekilde yapılması gerekmektedir. Erozyonun yoğun olması bölgedeki toprağın derinliğini ve verimini tehdit etmektedir.

Elde edilen bu veriler gelecekte yapılacak olan arazi ve toprak kaynaklarına yönelik proje ve çalışmalarda oldukça faydalı olacaktır. Bölgede yapılacak olan modern sulama sistemleri, akıllı tarım uygulamaları, erozyon önleme çalışmaları ve çiftçi eğitimleri ile Mardin geçmişte elde ettiği bereketli hilal adlandırılmasını günümüzde de yaşayarak ülkenin önemli tarım üretim alanlarındaki yerini üst sıralara taşıyacaktır.

\section{Kaynaklar}

Anonim, 1970. Mardin İli Toprak Kaynağı Envanter Haritası. Köy İşleri Bakanlığı Topraksu Genel Müdürlüğü, Yayın No: 131, Ankara.

Anonim, 1997. Mardin İli Arazi Varlığı. T.C. Başbakanlık Köy Hizmetleri Genel Müdürlüğü Yayınları, Ankara.

Anonim, 2002. 1/500.000 ölçekli Türkiye Jeoloji Haritası. Maden Tetkik ve Arama Genel Müdürlüğü, Ankara.

Anonim, 2018. CORINE Arazi Örtüsü Verisi. (https://land.copernicus.eu/pan-european/corine-land -cover/clc2018), (Erişim tarihi: 06.02.2019).

Anonim, 2019. Mardin İline Ait İstatistiki Veriler. T.C. Tarım ve Orman Bakanlığı Meteoroloji Genel Müdürlüğü Kayıtları. (https://www.mgm.gov.tr/ veridegerlendirme/il-ve-ilceler-istatistik.aspx? $\mathrm{k}=\mathrm{A} \&$ $\mathrm{m}=$ MARDIN), (Erişim tarihi: 20.10.2019). 
Atar, B., 2017. Gıdamız buğdayın, geçmişten geleceğe yolculuğu. Süleyman Demirel Üniversitesi Yalvaç Akademi Dergisi, 2(1): 1-12.

Aydan, C., Sabah, L., Yaman, N., Keser, K., 2016. Açık Kaynak Kodlu Coğrafi Bilgi Sistemleri ile Jeoloji Uygulamaları. TMMOB Jeoloji Mühendisleri Odas1 Yayınları, Yayın No: 128, Ankara.

Canpolat, O., 1981. Türkiye topraklarının tarımsal kullanıma uygunluk bakımından incelenmesi. DSI, Toprak ve Su Kaynaklarının Geliştirilmesi Konferansı, Cilt: 1, Ankara, s. 60-87.

Çorumluoğlu, Ö., Kalayc1, İ., Ceran, M.B., 2007. Bilgi toplumlarında modern tarım yaklaşımı: Hassas tarımda uydu ve bilgi sistemi teknolojileri (GPS, Uzaktan Alg1lama, CBS). Konya'da Tartm ve Tarımsal Sanayi Sorunlarının Tespiti Sempozyumu, 25-27 May1s, Konya, s. 333-343.

Demirci, A., 2008. Öğretmenler için CBS: Coğrafi Bilgi Sistemleri (GIS for Teachers). Fatih Üniversitesi Yayınları, Yayın No: 41, İstanbul.

Dengiz, O., Özyazıcı, M.A., 2018. Çeltik tarımına uygun alanların belirlenmesinde çok kriterli arazi değerlendirme. Toprak Bilimi ve Bitki Besleme Dergisi, 6(1): 19- 28.

Dengiz, O., Sağlam, M., Özaytekin, H.H., Baskan, O., 2013. Weathering rates and some physico-chemical characteristics of soils developed on a calcic toposequences. Carpathian Journal of Earth and Environmental Sciences, 8(2): 13-24.

Dengiz, O., Sarığlu, F.E., 2011. Samsun ilinin potansiyel tarım alanlarının genel dağılımları ve toprak ve etüd haritalama çalışmalarının önemi. Anadolu Tarm Bilimleri Dergisi, 26(3): 241-250.

Eryılmaz, H., Demirarslan, K.Ö., 2018. Artan küresel 1sınma ve duyarsızlaşan küresel politikalar. Artvin Çoruh Üniversitesi Uluslararasi Sosyal Bilimler Dergisi, 4(2): 52-69.

Karabulut, M., Küçükönder, M., 2008. Kahramanmaraş ovası ve çevresinde CBS kullanılarak erozyon alanlarının tespiti. Kahramanmaraş Sütçü Imam Üniversitesi Fen ve Mühendislik Dergisi, 11(2): 1422.

Karaca, S., Sarğın, B., Türkmen, F., 2019. Bazı arazi ve toprak niteliklerinin coğrafi bilgi sistem analizleriyle incelenmesi: Van ili arazi ve toprak özellikleri. Türkiye Tarımsal Araştırmalar Dergisi, 6(2): 199205.

Kavzoğlu, T., Çölkesen, İ., 2011. Uzaktan algılama teknolojileri ve uygulama alanları. Türkiye'de Sürdürülebilir Arazi Yönetimi Çalıştayı,26-27 Mayıs, İstanbul, s. 431-444.

Malthus, T., 1998. An Essay on the Principle of Population. (Electronic Scholarly Publishing Project), London. (http://www.esp.org/books/ malthus/population/malthus.pdf), (Erişim tarihi: 20.10.2019).
Özkalayc1, G.Ö., Özden, M., Keskin, S., Bayat, M., 2001. Türkiye toprakları bilgi sistemi. 8. Türkiye Harita ve Bilimsel Teknik Kurultay1, Harita ve Kadastro Mühendisleri Odas1, 19-23 Mart, Ankara, s. 266-270.

Özşahin, E., 2014. Tekirdağ ilinde CBS tabanlı RUSLE modeli kullanılarak erozyon risk değerlendirmesi. Tekirdă̆ Ziraat Fakültesi Dergisi, 11(3): 45-56.

Öztürk Coşar, G., Engindeniz, S., 2011. Tarım arazilerinin değerlendirilmesinde Coğrafi Bilgi Sistemlerinden yararlanma olanaklar1. Ege Üniversitesi Ziraat Fakültesi Dergisi, 48(3):283-290.

Özyazıc1, M.A., Dengiz, O., Aydoğan, M., Bayraklı, B., Kesim, E., Urla, Ö., Yıldız, H., Ünal, E., 2015. Orta ve Doğu Karadeniz Bölgesi tarım topraklarının bazı makro ve mikro bitki besin maddesi konsantrasyonları ve ters mesafe ağırlık yöntemi (IDW) ile haritalanması. Artvin Çoruh Üniversitesi Orman Fakültesi Dergisi, 16(2): 187-202.

Özyazıc1, M.A., Dengiz, O., Aydoğan, M., Bayraklı, B., Kesim, E., Urla, Ö., Yıldız, H., Ünal, E., 2016. Orta ve Doğu Karadeniz Bölgesi tarım topraklarının temel verimlilik düzeyleri ve alansal dağılımları. Anadolu Tarım Bilimleri Dergisi, 31(1): 136-148.

Özyazıc1, M.A., Dengiz, O., İmamoğlu, A., 2014. Siirt ili bazı arazi ve toprak özelliklerinin coğrafi bilgi sistem analizleriyle değerlendirilmesi. Türkiye Tarımsal Araştırmalar Dergisi, 1(2): 128-137.

Özyazıc1, M.A., Dengiz, O., Özyazıc1, G., 2017b. Spatial distribution of heavy metals density in cultivated soils of Central and East Parts of Black Sea Region in Turkey. Eurasian Journal of Soil Science, 6(3): 197205.

Özyazıc1, M.A., Dengiz, O., Sağlam, M., 2013. Artvin ilinde yonca (Medicago sativa L.) tarımı yapılan toprakların verimlilik durumu ve potansiyel beslenme problemlerinin ortaya konulması. Artvin Çoruh Üniversitesi Orman Fakültesi Dergisi, 14(2): 225238.

Özyazıcı, M.A., Dengiz, O., Sağlam, M., Erkoçak, A., Türkmen, F., 2017a. Mapping and assessment-based modeling of soil fertility differences in the Central and Eastern Parts of the Black Sea Region using GIS and geostatistical approaches. Arabian Journal of Geosciences, 10(2), Article: 45, 9p.

Şensoy, H., Palta, Ş., 2009. Yamaç şekillerinin toprak erozyonuna etkileri. Bartın Orman Fakültesi Dergisi, 11(15): 95-98.

Yomralığlu, T., 2005. Coğrafi Bilgi Sistemleri/Temel Kavramlar ve Uygulamalar. Güven Kitap Yayıları, İstanbul.

Zohary, D., Hopf, M., 2000. Domestication of plants in the Old World: The Origin and Spread of Cultivated Plants in West Asia, Europe, and the Nile Valley (3rd Edn.). Oxford University Press. United Kingdom. 